\title{
Circumscription of Gentiana harwanensis (Gentianaceae) and its addition to the flora of Eastern Himalaya
}

\author{
Debabrata Maity ${ }^{*}$, Mrinmoy Midday \& Jayanta Ghosh \\ Taxonomy and Biosystematics Laboratory, Department of Botany, University of Calcutta, \\ Ballygunge Circular Road, Kolkata, West Bengal - 700 019, India. \\ *E-mail: debmaity@yahoo.com
}

\begin{abstract}
Gentiana harwanensis G.Singh is reported for the first time from Eastern Himalaya. This taxon has been treated earlier as a subspecies of Gentiana capitata. It is reinstated here as a distinct species. A detailed description, photo plate, notes on distribution and habitat are provided for easy identification.
\end{abstract}

Keywords: Gentiana harwanensis, Gentianaceae, New Record, Sikkim, Status.

\section{Introduction}

Gentiana L. s.l. (Gentianaceae-Gentianeae) consisting of about 365 species is widely distributed in the temperate and alpine regions of North-West Africa (Morocco), America, Asia, eastern Australia and Europe (Garg, 1987; Ho \& Pringle, 1995; Maity, 2014; Anilkumar et al., 2015; Mabberley, 2017; Maity et al., 2018a, b). India harbours c. 69 species and most of them are distributed in the Himalayas.

During a plant collection trip to Lachung and its surrounding areas of north Sikkim, the authors collected a few specimens of Gentiana from subalpine grassy slopes. After comprehensive literature search (Clarke, 1883; Agarwal et al., 1981; Agarwal \& Bhattacharyya, 1982; Ubolcholaket, 1987; Garg, 1987; Ho \& Pringle, 1995; Aitken, 1999; Ho \& Liu, 2001; Hul, 2003), critical examination of specimens in consultation with the type and protologue and comparison of Gentiana

Received: 05.08.2019; Revised \& Accepted: 28.12.2019 Published Online: 31.12.2019 species of the Himalaya (India, Nepal, Bhutan, Tibet), the specimens were identified as Gentiana harwanensis G.Singh, which became a new record for Eastern Himalaya. Detailed description and photo plate are provided for easy identification. The circumscription of the species is also discussed and species status of Gentiana harwanensis is retained.

\section{Materials and Methods}

Plant specimens were collected from grassy slopes of Lachung Valley, North Sikkim at an elevation of about $2800 \mathrm{~m}$. Habit and habitat photographs were taken and voucher specimens were deposited at CUH. Measurements of vegetative and floral parts were taken with a Leica EZ4E stereo microscope. Type (images) and protologue, and other authentic specimens deposited in CAL, $\mathrm{KASH}, \mathrm{K}$ and NY were also examined.

\section{Taxonomic treatement}

Gentiana harwanensis G.Singh in G.Singh \& P.Kachroo, Forest Fl. Srinagar 126, t. 5. 1976; Agrawal et al., Indian J. For. 4 (3): 236. 1981; Agarwal \& Bhattacharyya, J. Econ. Taxon. Bot. 3: 999. 1982; Garg, Gent. N.E. Himal. 106. 1987. Ciminalis harwanensis (G.Singh) Omer, Edinb. J. Bot. 50(1): 67. 1993. Gentiana capitata Buch.Ham. ex D.Don subsp. harwanensis (G.Singh) Halda, Acta Mus. Richnov. Sect. Nat. 3: 36. 1995; Shabir et al., Check List 15(1): 107. 2019. Type: INDIA, Kashmir, Harwan, 25.04.1969, 1700 m, Gurucharan Singh 1524 (holo KASH digital image!; iso NY digital image!).

Fig. 1 


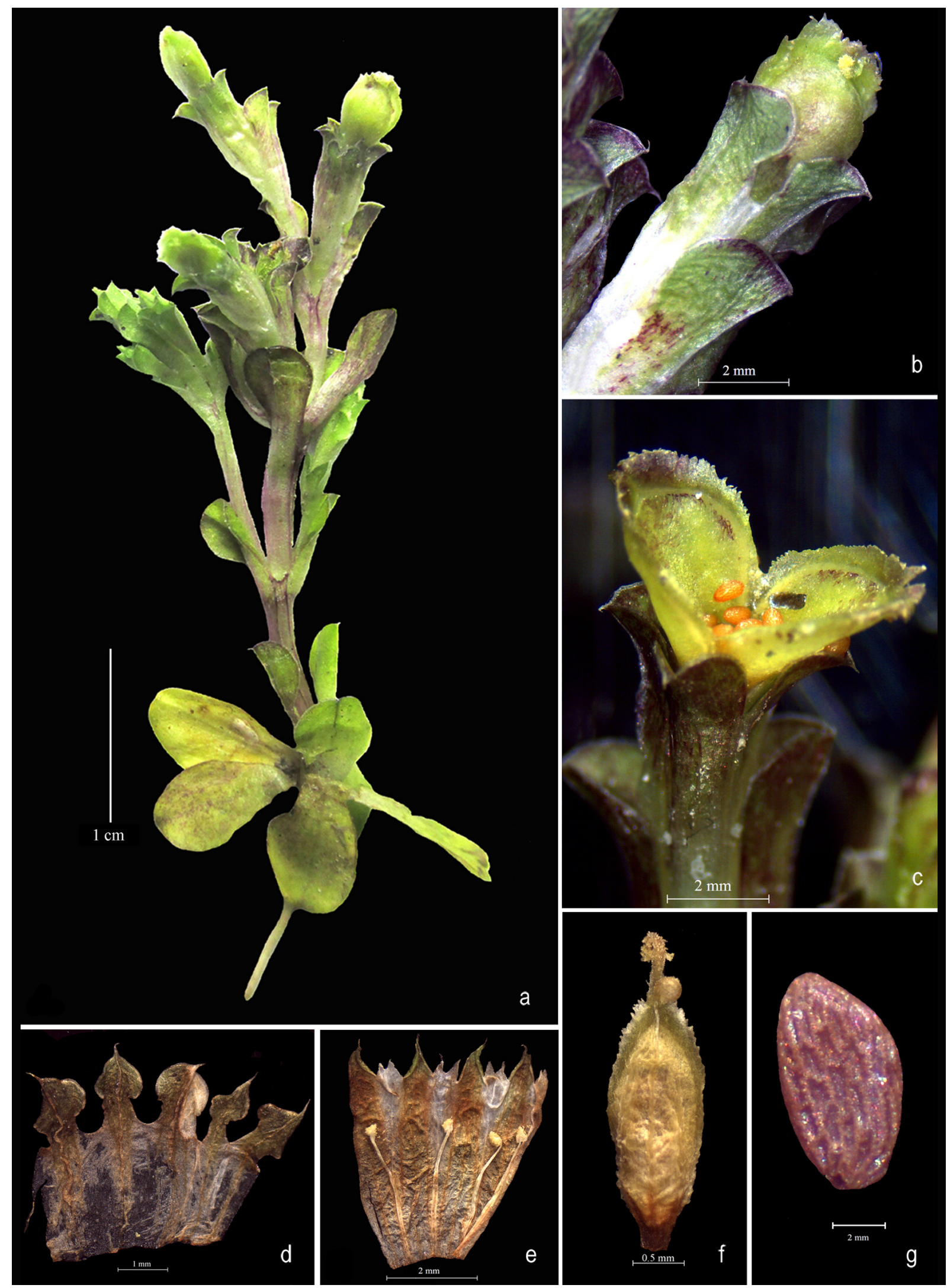

Fig. 1. Gentiana harwanensis G.Singh: a. Habit; b. Mature capsule; c. Dehisced capsule; d. Calyx - split open; e. Calyx - split open showing stamens; f. Gynoecium; g. Seed. 
Erect annual herbs, 2-8 cm tall; taproot cylindrical, c. $3 \mathrm{~cm}$ long, c. $0.4 \mathrm{~mm}$ diam.; stems simple or with few a branches above, angular often with fine purple lines, glabrous. Rosette leaves a few, present during anthesis; leaf blades spathulate, obovate or broadly elliptic 5-1 × 3-4(-9) mm, acute or rounded, mucronate, mucro cartilaginous, recurved, margins entire, smooth, cartilaginous; petioles short, c. $0.2 \mathrm{~mm}$ long, base fused to $c .0 .15 \mathrm{~mm}$ long sheath, glabrous, midvein prominent, cartilaginous. Cauline leaves dense to lax, 3-4 pairs, shorter than internodes; leaf blade spathulate or oblanceolate $4-7(-1) \times 3-4(-8)$ $\mathrm{mm}$, smooth, apex acute, often purplish tinged, mucronate, mucro cartilaginous, recurved, margins entire, cartilaginous, midvein cartilaginous; petioles fused, forming a sheath $0.25-0.5 \mathrm{~mm}$ long, smooth. Flowers terminal, solitary or a few, often in dichotomous pattern, sometimes condensed, 4(-5)merous; pedicels $c .1 \mathrm{~mm}$ long, often surrounded by upper most pair of leaves, glabrous. Calyx campanulate, 3.3-5.5 × 1.5-2.2 mm; tube 2-3.5 mm long; lobes 4 or 5 , broadly obovate or oblong, $1.3-3 \times 0.7-1.2(-2) \mathrm{mm}$, subequal, margins cartilaginous, apex acute, mucronate, often purplish, 1-veined, moderately reflexed; midvein cartilaginous, sinus between lobes rounded or obtuse. Corolla campanulate, 4.8-7 mm long, bluish; tube 4-6 mm long; lobes 4 or 5 , broadly ovate, $0.8-1.5(-3) \times$ $0.8-1(-3) \mathrm{mm}$, apex acute; plicae ovate, $0.5-0.7 \times$ $0.5-0.8 \mathrm{~mm}$, bifid. Stamens 4 or 5 , inserted below middle of corolla tube, $2.1-2.3 \mathrm{~mm}$ above corolla base; filaments 1-1.2(-4) mm long, white, slightly flattened towards base; anthers $0.5-1 \mathrm{~mm}$ long, yellow. Ovary ellipsoid, 2-3 × 1-2 mm, narrowly winged along ventral suture towards apex; stipe 0.5-0.7 mm long; style 0.4-1 mm long; stigma lobes oblong, $0.5-0.7 \mathrm{~mm}$. Capsules obovoid to club-shaped, 4.5-5 ×2-3 mm; ventral suture winged, crested at apex, partially exserted, many-seeded; fruiting pedicel c. $3.5 \mathrm{~mm}$ long; seeds ellipsoid, $c$. $0.75 \times 0.4 \mathrm{~mm}$, reddish brown, reticulate

Distribution: India.

Habitat: On rocks, grassy slopes and loose soil in open temperate to sub-alpine forests above 1700 to 4000 m elevation.
Flowering: February-May; fruiting: April-June.

Specimen examined: INDIA, Sikkim, below Lachung Valley, 2800 m, 10.03.2017, Dey, Ghosh \& Midday 20127, 20134 (CUH).

\section{Discussion}

Singh (1976) described Gentiana harwanensis and considered G. aquatica L. as its morphologically allied species. Agrawal et al. (1981) reassessed the relationship of the species and stated that "G. harwanensis is more closely allied to G. riparia Kar. et Kir., G. albicalyx Burkill, G. capitata Buch.Ham. ex D.Don rather than to G. aquatica L. and amended the description of the former species. Agrawal and Bhattacharyya (1982) subsequently considered G. capitata as more close to G. harwanensis. Phenologically G. harwanensis is more close to G. capitata than to G. aquatica as they flower early in the season (April-May), whereas latter species starts flowering in June. Garg (1987) in his revisionary account of the family Gentianaceae of the North West Himalaya retained G. harwanensis as a distinct species. However, Halda (1995) reduced G. harwanensis as a subspecies of G. capitata. Recently, Shabir et al. (2019) recorded it from Suru Valley in Kargil district of Ladakh and followed Halda (1995).

Gentiana capitata is characterized by stems being leafless in lower half, leaves congested into a dense head towards apex and plicae rounded and denticulate (rarely entire or with 2-3 dentate, thus sometimes appears as emarginate). However, the stems of $G$. harwanensis are leafy throughout with prominent basal rosettes. The basal rosette leaves are a few and present during anthesis. The plicae in $G$. harwanensis, is distinctly bifid and the inflorescence is much lax and never appears as congested head as in G. capitata (Table 1). Hence G. harwanensis, is treated as a distinct species following Singh (1976), Agrawal et al. (1981), Agrawal and Bhattacharyya (1982) and Garg (1987).

Gentiana harwanensis was described as endemic to Jammu and Kashmir by Singh (1976). Later, its occurrence in Uttarakhand state was confirmed by Agrawal et al. (1981), Agrawal and Bhattacharyya 
Table 1. Comparison of the diagnostic traits of G. harwanensis and G. capitata

\begin{tabular}{|l|l|l|}
\hline Characters & G. harwanensis & G. capitata \\
\hline Stem & angular, leafy throughout & terete, leafless in lower half \\
\hline Basal rosette & $\begin{array}{l}\text { present } \\
\text { Cauline leaves }\end{array}$ & arrangement \\
\cline { 2 - 4 } & $\begin{array}{l}\text { distributed throughout the stem, } \\
\text { not aggregated or congested }\end{array}$ & $\begin{array}{l}\text { aggregated and congested below a } \\
\text { dense head towards apex }\end{array}$ \\
\hline Inflorescence & $\begin{array}{l}\text { spathulate or oblanceolate } \\
\text { oblong, ovate, elliptic or spathulate }\end{array}$ \\
\hline Plicae & $\begin{array}{l}\text { flower solitary or a few, } \\
\text { often in lax dichotomous cymes }\end{array}$ & $\begin{array}{l}\text { flowers several to many, } \\
\text { in congested heads }\end{array}$ \\
\hline Capsule & $\begin{array}{l}\text { ovate, bi-fid } \\
\text { orbicular, semiorbicular } \\
\text { or oblong, entire or denticulate } \\
\text { crested at apex only }\end{array}$ \\
\hline
\end{tabular}

(1982) and Garg (1987). In a recent enumeration, Gupta et al. (2012) claimed the existence of this taxon in Himachal Pradesh, however, they did not cite any representative specimens. Shabir et al. (2017) mentioned Jammu and Kashmir as the only distribution locality of the species. However, both Agrawal et al. (1981), Agrawal and Bhattacharyya (1982) and Garg (1987) provided representative specimens from Uttarakhand (the then part of Uttar Pradesh). Even though, Agrawal and Bhattacharyya (1982) included Sikkim as one of the growing localities of the species, however they did not cite any specimen to justify their observation.

\section{Acknowledgements}

Authors are thankful to the Ministry of Environment, Forest \& Climate Change, Govt. of India, New Delhi for financial assistance; the Forests, Environment and Wildlife Management Department, Govt. of Sikkim, Home Department, Govt. of Sikkim, Superintendent of Police, Gangtok and Indo-Tibetan Border Police and $17^{\text {th }}$ Mtn. Division, Indian Army for permission and support for field visit. Authors are grateful to Dr. K.N. Gandhi (GH) for his comment on Gentiana amblyophylla and to the Director, Botanical Survey of India, Kolkata for giving permission to consult herbarium (CAL). Authors are thankful to S.K. Dey for help in field collection. Thanks are due to Dr. Anzar A. Khuroo
(University of Kashmir) for providing valuable literature.

\section{Literature Cited}

AGRAWAL S., BHATTACHARYYA U.C. \& B.K. GUPTA 1981. A note on Gentiana harwanensis (Gentianaceae). Indian Journal of Forestry 4(3): 236-238.

AGRAWAL S. \& U.C. BHATTACHARYYA 1982. Studies on Gentiana capitata Buch.-Ham. ex D. Don and its allies (Gentianaceae). Journal of Economic Taxonomic Botany 3: 995-1000.

AITKEN E. 1999. Gentianaceae. In: LONG D.G. (ed.), Flora of Bhutan. Volume 2(2). Royal Botanic Garden Edinburgh, Edinburgh. pp. 632-656.

ANILKUMAR K.A., PRABHU KUMAR K.M. \& P.S. UDAYAN 2015. Gentiana kurumbae, a new species of Gentianaceae from the Western Ghats of Kerala, India. Taiwania 60(2): 81-85.

CLARKE C.B. 1883. Gentianaceae. In: HOOKER J.D. (ed.), The Flora of British India. Volume 4. L. Reeve \& Co., London. pp. 108-119.

GARG S. 1987. Gentianaceae of the North West Himalaya ( $A$ Revision). Today \& Tomorrow's Printers and Publishers, New Delhi. pp. 80-122.

GUPTA S., MUKHERJEE A. \& M. MONDAL 2012. A census of Gentiana L. in India, Systematics of Flowering Plants, In: MAITI G. \& S.K. MUKHERJEE (eds.), Multidisciplinary Approaches in Angiosperm Systematics., Volume 1. University of Kalyani, Kalyani. pp. 53-58.

HALDA J.J. 1995. Synopsis of the new system of the genus Gentiana. Acta Musei Richnoviensis 3: 33-49.

HO T.N. \& S.W. LIU 2001. A worldwide monograph of Gentiana. Science Press, Beijing. pp. 1-694. 
HO T.N. \& J.S. PRINGLE 1995. Gentianaceae. In: WU Z.Y. \& P.H. RAVEN (Eds.), Flora of China. (Gentianaceae through Boraginaceae). Volume 16. Science Press, Beijing, and Missouri Botanical Garden Press, St. Louis. pp. 15-97.

HUL S. 2003. Flore du Cambodge, du Laos et du Vietnam. Volume 31. Gentianaceae. Muséum National d'Histoire Naturelle, Paris. pp. 1-97.

MABBERLEY D.J. 2017. Mabberley's plant-book, A portable dictionary of plants, their classification and uses. Fourth Edition. Cambridge University Press, Cambridge. p. 382.

MAITY D. 2014. A new species of Gentiana (Gentianaceae) from the Sikkim Himalaya. Edinburgh Journal of Botany 71(3): 289-296.

MAITY D., MAITI G.G. \& A.S. CHAUHAN 2018. Flora of Kanchenjunga Biosphere Reserve, Sikkim. Botanical Survey of India, Kolkata. pp. 287-309.

MAITY D., DEY S.K., GHOSH J. \& M. MIDDAY 2018.
Gentiana aruniisp. nov.: tiny remarkable Gentiana from Sikkim Himalaya. Edinburgh Journal of Botany 75(1): 117-125.

SHABIR M., AGNIHOTRI P., HUSAIN D., TIWARI J.K. \& T. HUSAIN 2017. On the current status of the genus Gentiana L. (Gentianaceae) in India. Pleione 11(1): 16-24.

SHABIR M., KHUROO A. A., AGNIHOTRI P., TIWARI J.K. \& T. HUSAIN 2019. A range extension of Gentiana capitata Buch.-Ham. ex D.Don subsp. harwanensis (G.Singh) Halda (Gentianaceae) to Ladakh TransHimalaya, India. Check List 15(1): 105-108.

SINGH G. 1976. Gentiana harwanensis. In: SINGH G. \& P. KACHROO (eds.), Forest Flora of Srinagar and Plants of Neighbourhood. Bishen Singh Mahendra Pal Singh, Dehradun. pp. 126-127.

UBOLCHOLAKET A. 1987. Gentianaceae. In: SMITINAND T. \& K. LARSEN (eds.), Flora of Thailand. Volume 5(1). The Forest Herbarium, Royal Forest Department, Bangkok. pp. 72-92. 